\title{
Soil spiders (Arachnida: Araneae) in native and reforested Araucaria forests
}

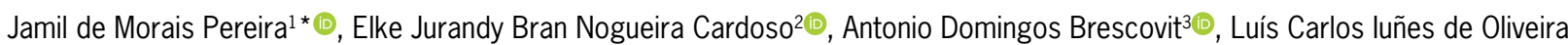
Filho $^{4}{ }^{\circledR}$, Julia Corá Segat ${ }^{5}$, Carolina Riviera Duarte Maluche Baretta ${ }^{6}$, Dilmar Baretta ${ }^{5}$

1Instituto Federal de Educacãa, Ciência e Tecnologia do Sul de Minas Gerais, Praça Tiradentes, 416 - 37576-000 Inconfidentes, MG - Brasil.

2Universidade de São Paulo/ESALQ - Depto. de Ciência do Solo, Av. Pádua Dias, 11 - 13418-900 - Piracicaba, SP Brasil.

3Instituto Butantan - Lab. Especial de Coleções Zoológicas, Av. Vital Brasil, 1500 - 05503-900 - São Paulo, SP - Brasil. ${ }^{4}$ Universidade Federal de Pelotas/FAEM - Depto. de Solos, Av. Eliseu Maciel, s/n - 96050-500 - Capão do Leão, RS Brasil.

${ }^{5}$ Universidade do Estado de Santa Catarina - Depto. de Zootecnia, R. Beloni Trombeta Zanin, 680E - 89815-630 Chapecó, SC - Brasil.

${ }^{6}$ Universidade Comunitária da Região de Chapecó, R. Servidão Anjo da Guarda, 295-D - 89809-900 - Chapecó, $\mathrm{SC}$ - Brasil.

*Corresponding author <jamilmpereira@gmail.com>

Edited by: Fernando Dini Andreote

Received July 24, 2019

Accepted October 28, 2019
ABSTRACT: Spiders are part of the soil biodiversity, considered fundamental to the food chain hierarchy, directly and indirectly influencing several services in agricultural and forest ecosystems. The present study aimed to evaluate the biodiversity of soil spider families and identify which soil properties influence their presence, as well as proposing families as potential bioindicators. Native forest (NF) and reforested sites (RF) with Araucaria angustifolia (Bertol.) Kuntze were evaluated in three regions of the state São Paulo, both in the winter and summer. Fifteen soil samples were collected from each forest to evaluate the biological (spiders and microbiological), chemical and physical soil properties, in addition to properties of the litter (dry matter and $\mathrm{C}, \mathrm{N}$ and $\mathrm{S}$ contents). For soil spiders, two sampling methods were used: pitfall traps and soil monoliths. In total, 591 individuals were collected, and distributed in 30 families, of which 306 individuals ( 22 families) came from pitfall traps and 285 individuals ( 26 families) from monoliths. Only samples obtained by the monolith method revealed seasonal differences in the mean density and richness of spiders between NF and RF. Canonical discriminant analysis showed the separation of these forests of Araucaria. Principal Component Analysis demonstrated the correlation of a number of spider families with certain soil properties (organic carbon, basal respiration, metabolic quotient, litter carbon, total porosity, bulk density and soil moisture). We identified 10 families (Anapidae, Corinnidae, Dipluridae, Hahniidae, Linyphiidae, Lycosidae, Nemesiidae, Palpimanidae, Salticidae, Scytodidae) that contributed most to separating native forest from the replanted forest, indicating the possibility of the spiders being used as bioindicators.

Keywords: spider fauna, soil biodiversity, soil properties, soil quality

\section{Introduction}

Spiders represent an extremely abundant group of terrestrial arthropod diversity, with more than 48,000 species described at global level so far, distributed over 117 families (World Spider Catalog, 2019). They represent a trophic level of consumers in the food chain and play a crucial role due to their predatory nature (Foelix, 2010; Jung et al., 2008a).

A number of authors have suggested that the structure of the environment may influence the abundance and richness of spider communities (Foelix, 2010). Their abundance and richness are strongly dependent on vegetation composition and structure (Oxbrough et al., 2007), landscape structure and disturbance (Rosa et al., 2018a, b; Schmidt et al., 2008), and soil properties (Rosa et al., 2018a, b). Thus, spiders have significant ecological importance for terrestrial, agricultural and forest ecosystems, where their role has been increasingly studied, evidencing edaphic factors that influence their presence and may provide useful information for monitoring environmental changes in most terrestrial ecosystems.

In Brazil, the devastation of forest areas has reached very significant proportions (Benati et al., 2005), requiring a joint effort for the collection and identification of terrestrial invertebrates in remaining areas. A. angustifolia, a native tree of the Mixed Ombrophilous forest from Brazil, is under the risk of extinction (Wrege et al., 2016). Inadequate exploration has led to a significant shrinkage of the original area and, currently, no more than $7 \%$ of the original forest area remains (Wrege et al., 2015). Knowledge of terrestrial invertebrates in the Araucaria Forest has increased over the last few years (Baretta et al., 2007; Pereira et al., 2017), since this area concentrates a high diversity of soil organisms and represents an important biological reserve for the preservation of biodiversity.

Studies already published (Baretta et al., 2007; Jung et al., 2008a, b; Rosa et al., 2018a, b) lead to an understanding that the fauna of soil spiders can also be used as a quality indicator in natural and agricultural ecosystems. In our study we hypothesized that the Araucaria forest under anthropic impact might interfere with the abundance, diversity and environmental variables (soil chemical, physical and microbiological properties) and help explain the distribution of soil spider families. Thus, the present study aimed to evaluate, in native and reforested Araucaria forests, the abundance and diversity of soil spider families, in addition to identifying which soil properties influence their presence and indicate the most important families as potential biological indicators in the separation of these forests. 


\section{Materials and Methods}

\section{Description of studied forests}

The study was carried out in three regions of the Mixed Ombrophilous forest, belonging to the Atlantic Forest Biome, in the state of São Paulo, Brazil. The climate is humid subtropical, with no dry season but the summers are mild ( $\mathrm{Cfb}$, according to Köppen's climate classification system) (Alvares et al., 2014). For all three zones, in the winter (Aug 2009), the mean temperature was $17{ }^{\circ} \mathrm{C}$ and rainfall was between 40-50 $\mathrm{mm}$, whereas in the summer (Feb 2010), the mean temperature was between $22-25{ }^{\circ} \mathrm{C}$ and rainfall registered more than $300 \mathrm{~mm}$. In each region, plots of approximately 1.0 ha were selected in native forest (NF) and reforestation (RF) with $A$. angustifolia (Bertol.) Kuntze. The native forests are more than 120 years old, while the reforested were planted between 20 and 45 years ago. The forests of each region were considered true replicates.

The first location for sampling NF and RF was subdivided into area 1 for native forest $(1,185 \mathrm{~m}$; $\left.22^{\circ} 48^{\prime} 26^{\prime \prime} \mathrm{S}, 44^{\circ} 21^{\prime} 59^{\prime \prime} \mathrm{W}\right)$ and area 2 for reforestation $\left(1,126 \mathrm{~m} ; 2^{\circ} 48^{\prime} 24^{\prime \prime} \mathrm{S}, 4^{\circ} 22^{\prime} 27^{\prime \prime} \mathrm{W}\right)$ (Pereira et al., 2013). The areas belong to the municipality of Bananal. The soil in NF (area 1) and RF (area 2) was classified as Dystric Haplic Cambisol (FAO, 2015).

The second region studied (area $3, \mathrm{NF} ; 678 \mathrm{~m}$; $23^{\circ} 50^{\prime} 27^{\prime \prime} \mathrm{S}, 49^{\circ} 08^{\prime} 40^{\prime \prime} \mathrm{W}$ ) is in the municipality of Itaberá, SP. In this region (area 4, RF; $740 \mathrm{~m} ; 24^{\circ} 04^{\prime} 19^{\prime \prime}$ S, $\left.49^{\circ} 04^{\prime} 10^{\prime \prime} \mathrm{W}\right)$ in the municipality of Itapeva, SP, there was a predominance of Araucaria and understory species. The soil in NF (area 3) and RF (area 4) were classified as Alumic Vetic Ferralsol and Eutric Ferralic Nitisol, respectively (FAO, 2015).

The third region is in the municipality of Barra do Chapéu (area 5, NF; $785 \mathrm{~m} ; 2^{\circ} 28^{\prime} 40^{\prime \prime} \mathrm{S}, 4^{\circ} 01^{\prime} 07^{\prime \prime} \mathrm{W}$ ) and the municipality of Iporanga (area 6, RF; $932 \mathrm{~m}$; $24^{\circ} 20^{\prime} 14^{\prime \prime} \mathrm{S}, 48^{\circ} 36^{\prime} 14^{\prime \prime} \mathrm{W}$ ). The soil in NF (area 5) and RF (area 6) was classified as Dystric Haplic Cambisol (FAO, 2015). More detailed descriptions regarding flora, physical and chemical soil properties in all areas can be found in Pereira et al. (2013).

\section{Experimental design and sampling}

The collections were carried out in the winter (Aug 2009) and the summer (Feb 2010). In each forest, 15 Araucaria trees with a minimum spacing of $20 \mathrm{~m}$ were chosen at random. Fifteen soil samples were collected to analyze the community of soil spiders, in addition to the microbiological, chemical and physical parameters, as well as the dry matter and chemical parameters of the litter. The samples were extracted from the forest floor at a distance of $2 \mathrm{~m}$ from the trunk of each tree.

For the evaluation of microbiological, chemical and physical properties, five subsamples were collected at each sampling point (tree), using a Dutch auger, in the $0-20 \mathrm{~cm}$ layer, making a total of 15 composite samples. The litter was sampled at the same point, in a $25 \times 25 \mathrm{~cm}$ area. For microbiological analysis, the samples were packed in polyethylene bags, refrigerated and transported to the laboratory in an ice-cooled box. Thereafter, the soil samples were sieved (2-mm mesh), ground and stored in a refrigerator $\left(4^{\circ} \mathrm{C}\right)$ until analysis. For chemical analysis, the samples were air-dried, sieved (2-mm mesh) and stored at room temperature. For physical analyses, both disturbed and undisturbed samples were collected. Disturbed soil samples were air-dried, sieved (2-mm mesh) and stored. In the winter, at the same sampling points, undisturbed samples were collected using stainless-steel rings $5 \mathrm{~cm}$ in diameter and the samples were kept intact and sealed (to avoid moisture loss) until the analyses.

\section{Sampling of soil spiders}

To avoid any underestimation of the density and diversity of the community of soil spiders and thus conduct a more accurate analysis of this community (Baretta et al., 2007; Brennan et al., 2005), and since the adoption of only one method may be ineffective, the following two sampling methods were used: pitfall traps and soil monoliths $(25 \times 25 \mathrm{~cm})$ in the layer from 0 to $20 \mathrm{~cm}$ (Baretta et al., 2007). Each trap consisting of one glass container $6 \mathrm{~cm}$ in diameter and $12 \mathrm{~cm}$ in height was buried in the soil, with its upper part open and level with the surface, and kept in place for three days. Each trap received $200 \mathrm{~mL}$ of neutral detergent solution at $2.5 \%$. The samples of the pitfall traps were successively passed through sieves of different mesh thicknesses $(0.2,0.15$ and $0.1 \mathrm{~mm})$. Before removing the soil monolith, the litter was sampled in the same area. The monoliths were collected using a galvanized iron implement (Baretta et al., 2007). The samples were manually screened to separate spiders from plant and soil fragments. The spiders collected by both methods were preserved in $75 \%$ alcohol solution until identification. These spider collection methods (monoliths and pitfall traps) have already been discussed in studies on spider ecology (Baretta et al., 2007; Brennan et al., 2005).

Since the identification of spider species is based on the presence of genital organs, which are developed only in adults, this study was carried out at family level only, in order to make use of the maximum possible number of individuals (Baretta et al., 2007). After identification, the individuals were labeled and preserved in $80 \%$ ethyl alcohol. All the material was deposited in the Arachnological collection of the Butantan Institute (A.D. Brescovit, curator). After identification, the following parameters were determined: abundance (individuals per trap, ind. trap $^{-1}$ ) for pitfall traps, density (individuals per square meter, ind. $\mathrm{m}^{-2}$ ) for monoliths, richness, Shannon's diversity index $(\mathrm{H})$ and Simpson's dominance index (Is). The indices were calculated using the PAST program v2.17c. 


\section{Soil chemical, physical and microbiological properties}

The soil chemical properties analyzed were $\mathrm{pH}$ $\left(\mathrm{CaCl}_{2}\right)$, exchangeable cations $\left(\mathrm{Al}^{3+}, \mathrm{Ca}^{2+}, \mathrm{Mg}^{2+}\right.$ and $\left.\mathrm{K}^{+}\right)$, $\mathrm{P}, \mathrm{H}+\mathrm{Al}$ and organic carbon content (C-org) (van Raij et al., 2001). In disturbed samples, the following soil properties were analyzed: particle size (Gee and Or, 2002) and soil moisture (Moist) (Embrapa, 2011). Undisturbed samples were analyzed for soil bulk density (Bd) (Blake and Hartge, 1986), total porosity (TP), microporosity (Mi) and macroporosity (Ma) (Embrapa, 2011).

For microbiological analyses, 100 -g soil samples with the moisture content corrected to $60 \%$ of maximum water retention capacity were used to quantify the microbial biomass carbon (MBC) (Vance et al., 1987), using the value of 0.33 as the correction factor in the calculations. Microbial activity was evaluated based on the determination of basal respiration $\left(\mathrm{C}-\mathrm{CO}_{2}\right.$ released) (Alef and Nannipieri, 1995). The metabolic quotient $\left(q \mathrm{CO}_{2}\right)$ was calculated by dividing the $\mathrm{C}-\mathrm{CO}_{2}$ released by $\mathrm{MBC}$, whereas the microbial quotient (qMic) was calculated by the expression (MBC/C-org)/10 (Anderson and Domsch, 1993).

The enzyme dehydrogenase $(\mathrm{DH})$ is very active in living cells and reflects the oxidative capacity of the soil microbial biomass. Dehydrogenase activity was quantified in soil samples (5 g at natural moisture), which received $5 \mathrm{~mL}$ of $1 \%$ triphenyl tetrazolium chloride (TTC) solution and were incubated at $37^{\circ} \mathrm{C}$ for $24 \mathrm{~h}$. The TTC used as electron acceptor is enzymatically reduced to triphenyl tetrazolium formazan (TTF) and was extracted with $10 \mathrm{~mL}$ of methanol. Enzyme activity was measured in a spectrophotometer at $485 \mathrm{~nm}$ /Casida Jr. et al., 1964).

\section{Litter dry matter and $\mathrm{C}, \mathrm{N}$ and $\mathrm{S}$ contents}

Litter dry matter (DM-Lt) was determined at $55^{\circ} \mathrm{C}$ until constant weight. Then, the litter was ground, passed through a 100-mesh sieve and its contents of C (C-Lt), N (N-Lt) and $\mathrm{S}$ (S-Lt) were determined by dry combustion in a simultaneous $\mathrm{C}, \mathrm{N}$, and $\mathrm{S}$ analyzer (Vario EL cube - Elementar).

\section{Statistical analysis}

Analysis of variance (ANOVA) of the main effects was used to compare the abundance (ind. $\operatorname{trap}^{-1}$ ), density (ind. $\mathrm{m}^{-2}$ ), richness and the $\mathrm{H}$ and Is indices between native and reforested forests, using the STATISTICA program v7.0. Data were transformed $(\sqrt{ } \mathrm{x}$ +1 ), when needed, to meet the normal distribution and homoscedasticity of error variances and were compared by LSD test $(p \leq 0.05)$. The LSD test was performed to compare the forests in each season and collection methods.

Data of density and abundance of soil spider families were subjected to Principal Components Analysis (PCA) for the periods studied (winter and summer), using the CANOCO 4.0 program. Only the significant $(p \leq 0.05)$ chemical ( $\mathrm{P}$ and $\mathrm{C}$-org), physical $(\mathrm{Bd}, \mathrm{TP}, \mathrm{Moist})$ and microbiological properties of the soil $\left(\mathrm{MBC}, \mathrm{C}-\mathrm{CO}_{2}\right.$ and $q \mathrm{CO}_{2}$ ) and of the litter (C-Lt and DM-Lt) were used as passive explanatory environmental variables, so as to increase the robustness of the analysis.

Additionally, the main families of soil spiders and their main properties were subjected to Canonical Discriminant Analysis (CDA) to identify which were the most relevant to the separation of the forests, using the parallel discriminant ratio (Pereira et al., 2017) in the SAS program, version 8.2.

Both analyses were used because they present different ideas. PCA was performed to verify the association of taxonomic fauna groups with the studied forests, subsequently using an indirect gradient, and the explanatory environmental variables (only those significant at 0.05 probability level) to help explain the reason for the preferential presence of the organisms in the different forests. On the other hand, CDA was carried out to separate the systems studied and confirm (through an associated statistical test) whether any separation between the systems could be detected, in addition to verifying which families contributed most to the separation. The use of PCA and CDA has already been published, in connection with other soil use systems and organisms (Pereira et al., 2017).

\section{Results}

\section{Univariate analysis}

A total of 591 individuals were collected, distributed over 30 families. Of these, 306 individuals, from 22 families, were collected in pitfall traps and 285 $\left(4560 \mathrm{~m}^{-2}\right)$ individuals, from 26 families, in monoliths. Considering both sampling methods and regardless of the period, the most frequent families relative to the total (591) were Linyphiidae (199 ind., $34 \%$ ), Theridiidae (70 ind., $12 \%$ ), Dipluridae (50 ind., $9 \%$ ), Oonopidae (44 ind., $8 \%$ ) and Corinnidae (34 ind., $6 \%$ ), representing $67 \%$ of the individuals collected (Table 1).

As per the pitfall trap method, none of the attributes of Araneae families differed $(p>0.05)$ between the forests in the two sampling periods. By contrast, as per the soil monolith method, there was a difference $(p \leq 0.05)$ between the forests in the summer, with mean densities of 52 ind. $\mathrm{m}^{-2}$ in NF and 26 ind. $\mathrm{m}^{-2}$ in RF. The same occurred for the mean richness, with 2 families in NF and 1 in RF (Table 1). Although there were no differences $(p>0.05)$ in the values of richness of families and $\mathrm{H}$, there was always a slight increase in

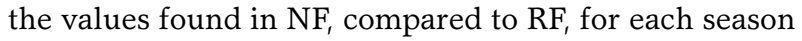
and collection method (Table 1).

\section{Principal Component Analysis (PCA)}

According to PCA, it is possible to verify that the factors that best explain the differences are the higher $\mathrm{C}$ content of the litter in $\mathrm{NF}$, in addition to higher soil moisture, porosity, $\mathrm{P}, \mathrm{MBC}$ and $\mathrm{C}-\mathrm{CO}_{2}$ in $\mathrm{RF}$. On the 
Table 1 - Number of individuals collected by pitfall traps and soil monoliths, in the winter and summer, in each family of soil spiders in native (NF) and reforested (RF) Araucaria forests, in addition to certain attributes of the families of Araneae.

\begin{tabular}{|c|c|c|c|c|c|c|c|c|c|}
\hline \multirow[b]{3}{*}{ Families } & & \multicolumn{4}{|c|}{ Pitfall traps } & \multicolumn{4}{|c|}{ Soil monoliths } \\
\hline & & \multicolumn{2}{|c|}{ Winter } & \multicolumn{2}{|c|}{ Summer } & \multicolumn{2}{|c|}{ Winter } & \multicolumn{2}{|c|}{ Summer } \\
\hline & & $\mathrm{NF}$ & $\mathrm{RF}$ & NF & $\mathrm{RF}$ & $\mathrm{NF}$ & $\mathrm{RF}$ & $\mathrm{NF}$ & $\mathrm{RF}$ \\
\hline Amaurobiidae & Ama & 0 & 0 & 0 & 0 & 32 & 0 & 0 & 0 \\
\hline Anapidae & Ana & 1 & 1 & 0 & 1 & 48 & 0 & 0 & 0 \\
\hline Anyphaenidae & Any & 0 & 0 & 0 & 0 & 0 & 16 & 0 & 0 \\
\hline Araneidae & Ara & 0 & 1 & 2 & 1 & 16 & 16 & 16 & 16 \\
\hline Caponiidae & Cap & 0 & 0 & 0 & 0 & 0 & 0 & 16 & 0 \\
\hline Corinnidae & Cor & 3 & 0 & 12 & 7 & 16 & 16 & 144 & 16 \\
\hline Ctenidae & Cte & 3 & 1 & 6 & 1 & 16 & 0 & 80 & 32 \\
\hline Dipluridae & Dip & 2 & 1 & 0 & 0 & 0 & 0 & 624 & 128 \\
\hline Gnaphosidae - Gnaphosinae & Gna & 0 & 0 & 2 & 1 & 0 & 0 & 128 & 0 \\
\hline Gnaphosidae - Prodidominae & Prod & 0 & 2 & 0 & 0 & 32 & 0 & 192 & 64 \\
\hline Hahniidae & Hah & 5 & 4 & 0 & 11 & 0 & 32 & 16 & 16 \\
\hline Idiopidae & Idio & 0 & 0 & 0 & 0 & 16 & 0 & 0 & 16 \\
\hline Linyphiidae & Liny & 44 & 47 & 22 & 38 & 192 & 64 & 352 & 160 \\
\hline Liocranidae & Lio & 1 & 0 & 0 & 0 & 0 & 0 & 32 & 32 \\
\hline Lycosidae & Lyc & 0 & 3 & 1 & 6 & 0 & 0 & 0 & 0 \\
\hline Mysmenidae & Mys & 0 & 0 & 2 & 0 & 0 & 0 & 0 & 0 \\
\hline Nemesiidae & Nem & 0 & 2 & 0 & 0 & 0 & 144 & 32 & 128 \\
\hline Oonopidae & Oon & 3 & 1 & 8 & 4 & 64 & 16 & 208 & 160 \\
\hline Palpimanidae & Palp & 1 & 0 & 0 & 0 & 0 & 0 & 16 & 0 \\
\hline Pholcidae & Phol & 0 & 0 & 1 & 0 & 0 & 0 & 16 & 0 \\
\hline Pisauridae & Pisa & 0 & 0 & 0 & 0 & 0 & 0 & 16 & 0 \\
\hline Salticidae & Salt & 0 & 2 & 5 & 2 & 48 & 0 & 112 & 112 \\
\hline Scytodidae & Scy & 0 & 1 & 0 & 0 & 16 & 0 & 0 & 16 \\
\hline Segestriidae & Sege & 0 & 0 & 0 & 0 & 0 & 0 & 16 & 0 \\
\hline Sparassidae & Spar & 0 & 0 & 0 & 1 & 0 & 0 & 0 & 16 \\
\hline Tetragnathidae & Tetra & 1 & 0 & 2 & 2 & 0 & 0 & 0 & 0 \\
\hline Theraphosidae & Thera & 0 & 0 & 0 & 0 & 16 & 0 & 80 & 32 \\
\hline Theridiidae & Ther & 11 & 8 & 10 & 6 & 64 & 48 & 224 & 224 \\
\hline Theridiosomatidae & Theri & 1 & 0 & 1 & 0 & 0 & 0 & 0 & 0 \\
\hline Thomisidae & Thom & 0 & 0 & 0 & 1 & 0 & 48 & 0 & 16 \\
\hline Zodariidae & Zod & 0 & 0 & 0 & 0 & 0 & 0 & 16 & 64 \\
\hline Total of individuals & & 76 & 74 & 74 & 82 & 576 & 400 & 2336 & 1248 \\
\hline Mean of individuals* & & $2 \pm 2$ & $2 \pm 2$ & $2 \pm 1$ & $2 \pm 2$ & $13 \pm 22$ & $9 \pm 14$ & $52 a \pm 49$ & $26 b \pm 29$ \\
\hline Total richness & & 12 & 13 & 13 & 14 & 13 & 9 & 19 & 18 \\
\hline Mean richness & & $1 \pm 1$ & $1 \pm 1$ & $1 \pm 1$ & $1 \pm 1$ & $1 \pm 1$ & $0.5 \pm 1$ & $2 a \pm 2$ & $1 b \pm 1$ \\
\hline Shannon's diversity $(\mathrm{H})$ & & $0.22 \pm 0$ & $.19 \pm 0.34$ & $0.36 \pm 0.47$ & $0.26 \pm 0.43$ & $0.09 \pm 0.24$ & $0.06 \pm 0.19$ & $0.53 \pm 0.58$ & $0.30 \pm 0.47$ \\
\hline Simpson's dominance (Is) & & $0.20 \pm 0$ & $.21 \pm 0.37$ & $0.37 \pm 0.46$ & $0.25 \pm 0.40$ & $0.10 \pm 0.26$ & $0.07 \pm 0.25$ & $0.43 \pm 0.43$ & $0.31 \pm 0.44$ \\
\hline
\end{tabular}

other hand, certain of the parameters studied $\left(\mathrm{pH}, \mathrm{Al}^{3+}\right.$, $\mathrm{Ca}^{2+}, \mathrm{Mg}^{2+}, \mathrm{K}^{+}, \mathrm{H}+\mathrm{Al}$, particle size, $\mathrm{Mi}, \mathrm{Ma}, q \mathrm{Mic}, \mathrm{DH}$, $\mathrm{N}-\mathrm{Lt}$ and S-Lt) in this forest, showed no relation with soil spider families. This is important, because in future research studies there will be no need to evaluate these parameters, which will save time, material and human resources.

The PCA separated the NF from the RF collected by pitfall traps. In the winter, the principal component 1 (PC1) represented $24 \%$ and the principal component 2 (PC2) represented $11 \%$. There was greater abundance of spiders in the NF (Figure 1A), where the soil is covered with litter containing higher levels of $\mathrm{C}$, which was found mainly in individuals from the Araneidae, Corinnidae, Hahniidae, Linyphiidae, Liocranidae, Palpimanidae, Theridiidae and Theridiosomatidae. The Anapidae, Oonopidae, Dipluridae and Nemesiidae families showed less association with $\mathrm{NF}$, and the RF was more associated with Salticidae, Scytodidae and Gnaphosidae - Prodidominae, which are related to soils with higher moisture contents. The Lycosidae, Ctenidae and Tetragnathidae families showed no specific tendency for any of these forests and were observed at sites with higher litter mass.

During the summer (Figure 1B), PC1 explained 24 $\%$ and PC2 explained $10 \%$ of the data variation, and 
A
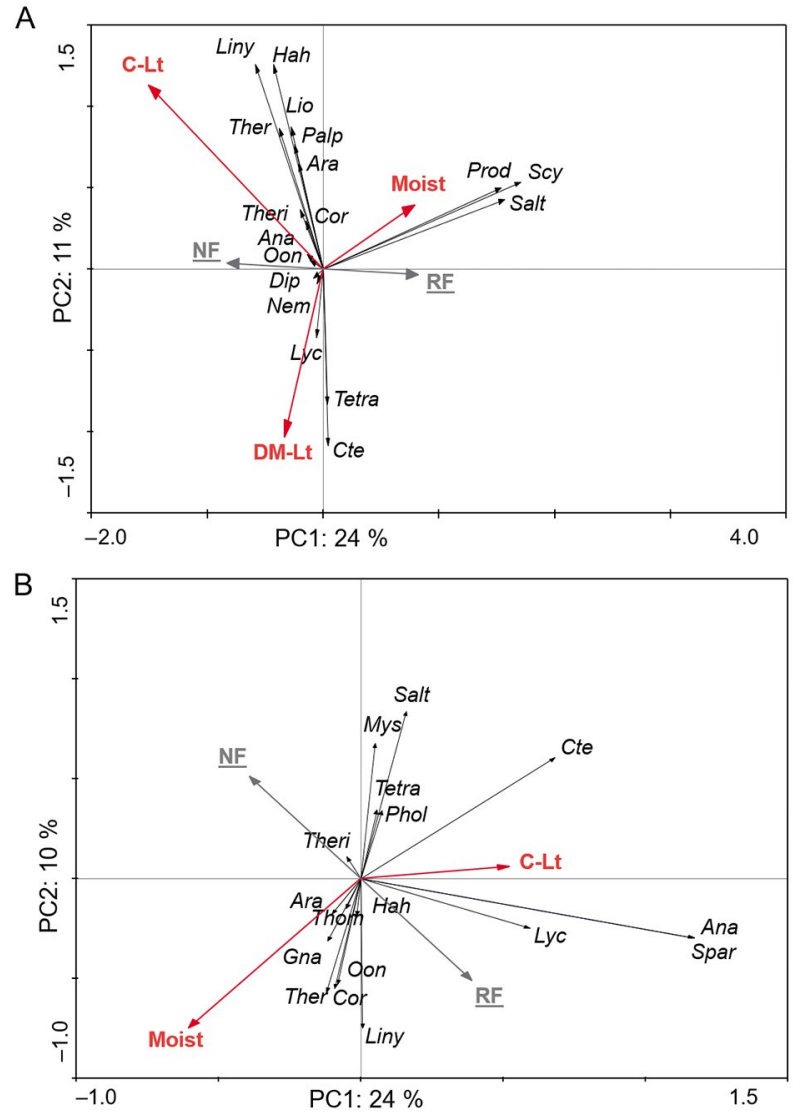

Figure 1 - Relationships between the principal components 1 (PC 1) and 2 (PC 2), separating native (NF) and reforested (RF) Araucaria forests, families of soil spiders (in italics) and explanatory environmental variables (in red) sampled with pitfall traps in the winter (A) and summer (B). Ana = Anapidae; $A r a=$ Araneidae; Cor = Corinnidae; Cte = Ctenidae; Dip = Dipluridae; Gna = Gnaphosidae - Gnaphosinae; Prod = Gnaphosidae - Prodidominae; Hah = Hahniidae; Liny = Linyphiidae; Lio = Liocranidae; Lyc = Lycosidae; Mys = Mysmenidae; Nem = Nemesiidae; Oon = Oonopidae; Palp = Palpimanidae; Phol = Pholcidae; Salt = Salticidae; Scy = Scytodidae; Spar = Sparassidae; Tetra = Tetragnathidae; Ther = Theridiidae; Theri $=$ Theridiosomatidae; Thom = Thomisidae. C-Lt = Litter carbon contents; DM-Lt = Litter dry matter; Moist $=$ Soil moisture. $\mathrm{PC} 1$ = Principal Component $1 ; \mathrm{PC} 2=$ Principal Component 2.

the highest number of families was more associated with the RF. Mysmenidae, Pholcidae, Salticidae, Tetragnathidae and Theridiosomatidae were associated with NF, while Anapidae, Araneidae, Corinnidae, Gnaphosidae - Gnaphosinae, Hahniidae, Linyphiidae, Lycosidae, Oonopidae, Sparassidae, Theridiidae and Thomisidae were associated with RF. Ctenidae did not show any specific association with the forests, but was very influenced by the litter C content (C-Lt). Similarly, Anapidae, Lycosidae and Sparassidae were greatly influenced by C-Lt, while Araneidae, Corinnidae,
Gnaphosidae - Gnaphosinae, Oonopidae, Theridiidae and Thomisidae were influenced by soil moisture.

For spiders sampled by the soil monolith method, the PCA detected a separation between NF and RF and a greater association of certain spider families with one kind of forest or the other. In the winter (Figure 2A), PC1 represented $21 \%$ and PC2 $10 \%$. The Anapidae, Corinnidae, Ctenidae, Linyphiidae, Salticidae and Scytodidae families were associated with $\mathrm{NF}_{\text {, with no }}$ correlation with the environmental variables, whereas Anyphaenidae, Araneidae, Hahniidae, Idiopidae, Amaurobiidae, Nemesiidae, Oonopidae, Gnaphosidae - Prodidominae, Theraphosidae, Theridiidae and Thomisidae were correlated with $\mathrm{RF}$, and their presence was favored in soil with higher contents of $\mathrm{P}, \mathrm{C}$-org and MBC. Other favorable factors were higher moisture content and total porosity, combined with greater soil respiration.

For the sampling with soil monoliths in the summer (Figure 2B), PC1 explained $19 \%$ and PC 8 $\%$ of variations in the data. Caponiidae, Corinnidae, Ctenidae, Dipluridae, Gnaphosidae - Gnaphosinae, Hahnidae, Pholcidae, Pisauridae, Salticidae, Segestriidae, Theridiidae and Thomisidae were more associated with NF, being influenced by soil density, whereas Araneidae, Idiopidae, Linyphiidae, Liocranidae, Nemesiidae, Oonopidae, Palpimanidae, Gnaphosidae - Prodidominae, Scytodidae, Sparassidae, Theraphosidae and Zodariidae were associated with $\mathrm{RF}$ and their presence was favored by soil moisture, $\mathrm{C}$ contents of soil and litter, and soil respiration.

\section{Canonical Discriminant Analysis (CDA)}

Differences between RF and NF were evaluated using canonical discriminant analysis, considering the attributes of environmental variables (chemical, physical and microbiological properties of soil and chemical properties of litter), and the presence of soil spider families. The Wilks' Lambda test for spider fauna attributes and environmental variables indicated discrepancies between winter and summer and types of forest (NF and RF) ( $p \leq 0.0001)$ by the canonical discriminant functions 1 (CDF1) and 2 (CDF2). Therefore, a CDA was performed for each sampling period (Figure 3). In addition, there were high canonical correlations in the pitfall trap method in both the winter (0.94) and summer (0.92), and in the soil monolith method, between winter (0.93) and summer (0.91). Thus, the CDA model used explained a great part of the variability present in the forests. The polarized distribution of Araucaria forests (native and reforested) indicates high dissimilarity between the forests studied, where CDF1 separated the NF from the RF (Figure 3).

Values of Parallel Discriminant Ratio (PDR) referring to the CDA (Table 2), which demonstrates the potential of each attribute of the families of soil spiders to discriminate soil quality, because they contributed more to the separation between the forests studied. 


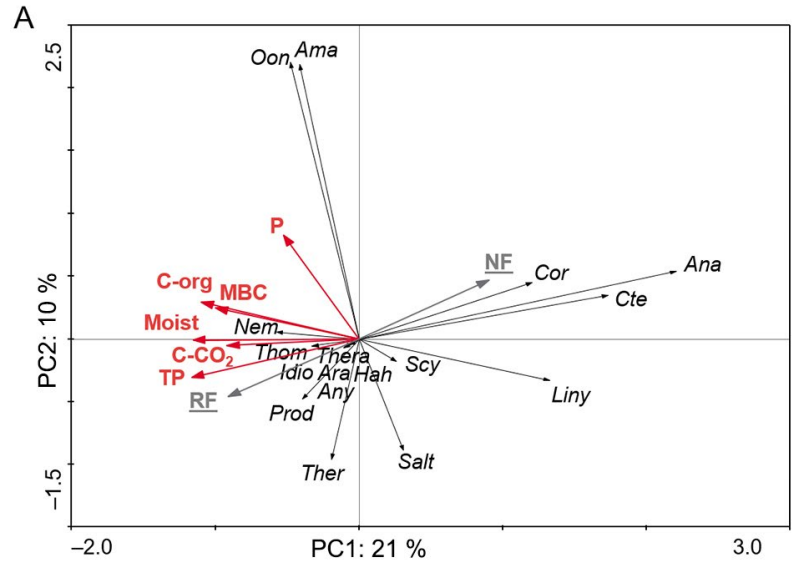

$\mathrm{B}$

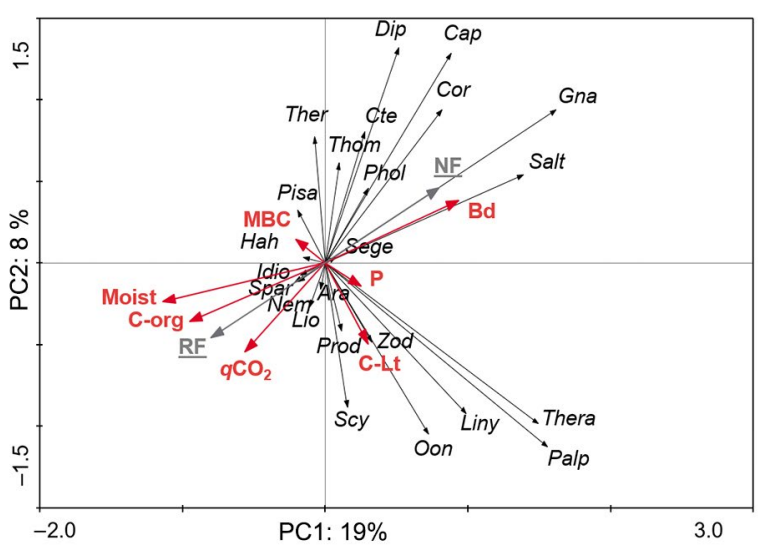

Figure 2 - Relationships between the principal components 1 (PC 1) and 2 (PC 2), separating native (NF) and reforested (RF) Araucaria forests, families of soil spiders (in italics) and explanatory environmental variables (in red) sampled with soil monoliths $(25 \times 25 \mathrm{~cm})$ in the winter (a) and summer (b). Ama = Amaurobiidae; Ana = Anapidae; Any = Anyphaenidae; Ara = Araneidae; $\mathrm{Cap}=$ Caponiidae; $\mathrm{Cor}=$ Corinnidae; $\mathrm{Cte}=$ Ctenidae; Dip = Dipluridae; Gna = Gnaphosidae - Gnaphosinae; Prod = Gnaphosidae - Prodidominae; Hah = Hahniidae; Idio = Idiopidae; Liny = Linyphiidae; Lio = Liocranidae; Nem = Nemesiidae; Oon = Oonopidae; Palp = Palpimanidae; Phol = Pholcidae; Pisa = Pisauridae; Salt = Salticidae; Scy = Scytodidae; Sege = Segestriidae; Spar = Sparassidae; Thera = Theraphosidae; Ther = Theridiidae; Thom $=$ Thomisidae; Zod $=$ Zodariidae. $\mathrm{Bd}=$ Bulk density; C-CO2 = Basal respiration; C-Lt = Litter carbon contents; C-org = organic carbon content; $\mathrm{MBC}=$ Microbial biomass carbon; Moist $=$ Soil moisture; $q \mathrm{CO} 2=$ Metabolic quotient; $\mathrm{P}=$ Phosphorus; TP = Total porosity. $\mathrm{PC1}=$ Principal Component 1 ; PC2 = Principal Component 2.

In general, other studies (Pereira et al., 2017) have shown good values, above 0.1 , to discriminate forests. However, the present study considered values above 0.02 only to discriminate the forests, because of the low number of individuals per family. Thus, Hahniidae (0.064), Lycosidae (0.025), Shannon's diversity (0.100) and Simpson's dominance (0.098) contributed to the
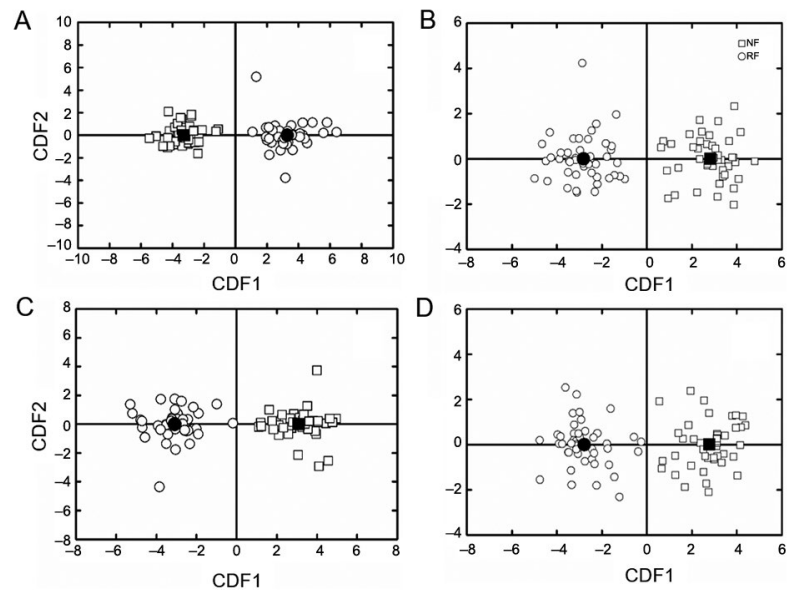

Figure 3 - Standardized canonical coefficients (SCC) of the canonical discriminant functions 1 and 2 (CDF1 and CDF2), discriminating native (NF) and reforested (RF) Araucaria forests, considering the properties of the environmental variables (chemical, physical and microbiological properties of soil and chemical properties of litter) and families of soil spiders collected with pitfall traps, in the winter (A) and summer (B), and with soil monoliths $(25 \times 25 \mathrm{~cm})$, in winter (C) and summer (D). Black symbols represent the mean value of SCC for each forest $(n=45)$.

separation of forests through the pitfall trap method, all in the summer. As per the soil monolith method, Anapidae (0.084), Linyphiidae (0.085), Salticidae (0.033), Scytodidae (0.035) and richness (0.112) contributed to the separation of forests in the winter, while in summer they were Corinnidae (0.029), Dipluridae (0.036), Nemesiidae (0.054), Palpimanidae (0.051), richness $(0.066)$ and Simpson's dominance (0.020) contributed in the summer.

\section{Discussion}

\section{Diversity of spider families}

Twenty six percent of the total families described at global level were collected in this study. Since there are no historical records for these forests in relation to the true local diversity, these families can serve as indicators for discriminating environments (Figure 3 and Table 2) (Jung et al., 2008a, b). The band of families found with the highest frequency in this study is also among the most abundant group of spiders in most Brazilian soil ecosystems, thus corroborating their representativeness (Benati et al., 2005; Brescovit et al., 2004; Rosa et al., 2018a).

The forest ecosystem conservation status had little influence on the richness and diversity of spider families. However, environmental stability was a determinant factor for the presence of Linyphiidae, when different soil use systems were evaluated in a gradient of anthropic intervention (Rosa et al., 2018a, b), corroborating all these studies. Other studies have reported not only higher abundance, but also a higher 
Table 2 - Values of Parallel Discriminant Ratio (PDR) referring to the Canonical Discriminant Analysis (CDA) for the attributes of the families of soil spiders in the winter and summer, regardless of the forest evaluated.

\begin{tabular}{|c|c|c|c|c|}
\hline & \multicolumn{4}{|c|}{ Parallel Discriminant Ratio } \\
\hline & \multicolumn{2}{|c|}{ Pitfall traps } & \multicolumn{2}{|c|}{ Soil monoliths } \\
\hline & Winter & Summer & Winter & Summer \\
\hline \multicolumn{5}{|l|}{ Families of soil spiders } \\
\hline Amaurobiidae & - & - & 0.000 & - \\
\hline Anapidae & $0.000^{*}$ & -0.001 & 0.084 & - \\
\hline Anyphaenidae & $-* *$ & - & 0.000 & - \\
\hline Araneidae & 0.003 & 0.004 & -0.002 & 0.000 \\
\hline Caponiidae & - & - & - & 0.018 \\
\hline Corinnidae & 0.015 & 0.012 & 0.000 & 0.029 \\
\hline Ctenidae & 0.008 & -0.001 & 0.000 & 0.015 \\
\hline Dipluridae & 0.001 & - & - & 0.036 \\
\hline Gnaphosidae - Gnaphosinae & - & -0.005 & - & -0.041 \\
\hline Gnaphosidae - Prodidominae & -0.007 & - & 0.000 & 0.011 \\
\hline Hahniidae & 0.004 & 0.064 & 0.000 & 0.000 \\
\hline Idiopidae & - & - & 0.000 & -0.003 \\
\hline Linyphiidae & -0.001 & -0.001 & 0.085 & -0.038 \\
\hline Liocranidae & -0.013 & - & - & 0.000 \\
\hline Lycosidae & -0.003 & 0.025 & - & - \\
\hline Mysmenidae & - & -0.015 & - & - \\
\hline Nemesiidae & -0.006 & & -0.139 & 0.054 \\
\hline Oonopidae & 0.016 & 0.005 & -0.006 & -0.011 \\
\hline Palpimanidae & 0.014 & - & - & 0.051 \\
\hline Pholcidae & - & -0.009 & - & 0.017 \\
\hline Pisauridae & - & - & - & 0.011 \\
\hline Salticidae & -0.007 & 0.010 & 0.033 & 0.000 \\
\hline Scytodidae & 0.007 & - & 0.035 & -0.012 \\
\hline Segestriidae & - & - & - & 0.007 \\
\hline Sparassidae & - & 0.000 & - & -0.014 \\
\hline Tetragnathidae & -0.007 & 0.000 & - & - \\
\hline Theraphosidae & - & - & 0.000 & -0.013 \\
\hline Theridiidae & 0.014 & -0.008 & -0.007 & 0.000 \\
\hline Theridiosomatidae & 0.000 & 0.011 & - & - \\
\hline Thomisidae & - & -0.011 & -0.075 & -0.003 \\
\hline Zodariidae & - & - & - & 0.005 \\
\hline \multicolumn{5}{|l|}{ Attributes of spider families } \\
\hline Organisms*** & -0.001 & 0.000 & 0.000 & 0.000 \\
\hline Richness & -0.003 & -0.025 & 0.112 & 0.066 \\
\hline Shannon's diversity (H) & 0.004 & 0.100 & 0.003 & -0.074 \\
\hline Simpson's dominance (Is) & -0.002 & 0.098 & 0.000 & 0.020 \\
\hline
\end{tabular}

*Positive values indicate the effects of separation between the native and reforested forests, whereas negative values indicate similarities. Boldface values represent the most important attributes for discriminating the forests studied $(n=45) .{ }^{* *}$ Indicates that there were no individuals collected. ${ }^{* * *}$ Refers to abundance when collected by soil traps and density when collected by soil monoliths.

richness of spiders in environments with greater stability, as is the case of native areas (Malumbres-Olarte et al., 2013; Pommeresche et al., 2013; Rodriguez-Artigas et al., 2016). In our survey, however, it was not possible to find results demonstrating such divergence in the mean abundance and total diversity of families. Additionally, on occasion considerable diversity can be found in more recently disturbed environments (Jung et al., 2008b). Other factors can be influencing the composition of soil spider families, such as climatic condition (MantykaPringle et al., 2015), floristic composition and diversity in the area (Jung et al., 2008b; Sabais et al., 2011), as well as the soil community as a whole, and are directly related to the spiders, either through the presence of food (such as springtails, mites and dipterans, which are important prey) (Gravesen, 2008; Pommeresche et al., 2013), or by the absence or presence of predators (Rosa et al., 2018a).

\section{Community distribution of soil spider families and their relationships with soil properties}

The structure and composition of the flora as a primordial factor modulates the composition of the spider community, but the differences in environmental conditions in the litter and soil have a substantial effect on the composition of the spider families (Oxbrough et al., 2007).

Only C-Lt had influence on the composition of the families associated with the NF for the winter. Therefore, Corinnidae was described as a family established in forests where temporal stability (over the periods) is greater (Rosa et al., 2018a) under different soil use systems. Here these spiders were found in the forest due to their habit of actively searching for prey (Lo-ManHung et al., 2011). Organic matter is very important to the biological complexity in various ecological niches. The favoring of accumulation of surface litter in quantity and quality maintains the microclimate and moisture, as well as the diversity of microhabitats at this site and this is favorable to various soil organisms that are attracted by the diversity of plant residues, becoming potential prey for spiders (Malumbres-Olarte et al., 2013; Rosa et al., 2018a). Thus, the C-Lt, C-org and other parameter linkage to organic matter, become an indirect conditioner for the abundance of spider families.

On the other hand, although the frequency of Linyphiidae has been reported in native areas (Almada and Sarquis, 2017; DiCarlo and DeBano, 2019), it has also been associated with higher contents of organic material in these areas (Rosa et al., 2018a), a consequence of higher C-Lt, pointing to a close association between the presence of these two indicators in NF. In addition, Rosa et al. (2018b) also reported higher frequency of organisms of this family in more stable areas (native pasture), compared to no-tillage areas. The relationship between NF and Palpimanidae is a consequence of the feeding behavior of this family, in which several species are known for their reduced movement in the search for food (Cerveira and Jackson, 2005) and they are more associated with the soil and superficial litter (Rosa et al., 2018a), which results in their greater presence in native areas, being more easily captured by the methods used here. Associated with NF, Corinnidae, Linyphiidae and Palpimanidae were highly sensitive to the environmental conditions or changes, being responsible for the 
separation of NF and RF (Figure 3) through the values of parallel discriminant ratios (Table 2).

In the winter, soil moisture was relevant to the separation of the forest types (Figures $1 \mathrm{~A}$ and 2A), and this factor reflects on the presence of soil spider families. Increase in the moisture gradient favored the density of spiders in peatlands compared to improved grasslands (Kajak et al., 2000). In addition, soil moisture may indirectly affect spiders through its influence on vegetation development (Cattin et al., 2003), favoring the formation of microhabitats with great humidity that are favorable to spiders and their prey.

Spider families influenced by other properties and, in turn, associated with $\mathrm{RF}_{\text {, }}$ as in the case of Gnaphosidae - Prodidominae, have also been reported as being present in native Araucaria forest with reduced human intervention in the state of São Paulo, Brazil (Baretta et al., 2007), although little is known about this family (Rosa et al., 2018a). Idiopidae was reported in a review by Rix et al. (2017) as common in stable areas of natural reserves, as in smaller or remaining reserves close to urban areas in Australia, despite being very rare. This fact seems to indicate that Araucaria reforestation fragments are already in an advanced stage of regeneration, thus enabling the emergence of families that seek more stabilized ecosystems. The same is valid for Oonopidae, which is associated with forest areas (Battirola et al., 2010), in addition to these spiders' close relationship with litter, where they search for food, and this is considered a developed environment (Rosa et al., 2018b).

The correlation between the different families and the forests was also influenced by the sampling period, since Linyphiidae was related to NF in the winter and $\mathrm{RF}$ in the summer. Such discrepancies in a different sampling period, for spider families has also been evidenced by other authors (Indicatti et al., 2008; Rosa et al., 2018b). In the cases of Nemesiidae, according to Rosa et al. (2018b), and Araneidae, according to Marc et al. (1999), associated with $\mathrm{RF}_{\text {, their representativeness }}$ occurred in the summer due to the reproduction cycle, because their eggs hatch in spring. Araneidae are considered generalists that do not undergo alterations in their community under different managements systems (organic and conventional) (Picchi et al., 2016), indicating their low capacity to be environmental indicators due to their high adaptability (Benati et al., 2005). The correlation of Palpimanidae with the forests was also influenced by the sampling period and, in the summer, they were more associated with $\mathrm{RF}$, as has already been described, probably due to their low mobility in search for food, making them more present in forests where litter permits greater presence of prey.

In both seasons, the moisture content, C-org and $q \mathrm{CO}_{2}$, in addition to C-Lt, were more associated with $\mathrm{RF}$, separating it from NF. This indicates that floristic quality and composition were important in this result, evidencing that the interactions of the spider fauna with the soil fauna in general are important determinants of the carbon cycle (Morriën et al., 2017). Anapidae are present in stable forests, but it is possible to note a strong association with C-Lt, since they were present in the forests where this attribute was significant for the separation, as determined by the PCA. Lycosidae, also influenced by C-Lt, has direct association with organic matter content and positive correlation with the soil cover (Birkhofer et al., 2018), being abundant in Eucalyptus reforestation (Rosa et al., 2018a). In southern Brazil, spiders of this family have been reported as syntropic organisms (Rosa et al., 2018b), generalists (Almada and Sarquis, 2017) and as inhabitants of degraded and regenerating environments (DiCarlo and DeBano, 2019). The wide distribution of these families and their capacity to be influenced by the characteristics of the soil environment indicate the possibility of their use as indicators of environmental changes in native or reforested Araucaria.

On the other hand, bulk density showed a strong association with $\mathrm{NF}_{\text {, an }}$ area that in turn showed higher abundance of spiders in this period. Physical variables are important for spider communities (Yang et al., 2017) and, in addition, variables such as soil density affect all trophic groups as well as spiders (Kajak et al., 2000; Rosa et al., 2018a). In the present study, soil density was determinant for the presence of Ctenidae in NF in the summer. This result demonstrates the importance of more stable environments throughout the year in the maintenance of soil organisms and spider fauna, since climatic changes can determine modifications in the composition of the spider fauna (Mantyka-Pringle et al., 2015).

Families associated with $\mathrm{NF}$ in general have a lower capacity for adapting to alterations and, therefore, are established in more stable environments, as in the case of Salticidae (DiCarlo and DeBano, 2019; Rosa et al., 2018a) and Caponiidae (Rosa et al., 2018a), and where the physical complexity of the areas favors the formation of webs such as for Tetragnathidae (Almada and Sarquis, 2017) or traps for Dipluridae (Brescovit et al., 2004). Certain spiders, such as Pholcidae, have the habit of actively seeking prey, and these are found in higher density in native areas (Malumbres-Olarte et al., 2013). Pholcidae was found exclusively in agriculturally unexplored areas when compared to grazing areas in southern Brazil (Silva and Ott, 2017) and genera of this family were found in Restinga areas at different stages of environmental regeneration (primary, medium and advanced) (Benati et al., 2005). Only four species of this family are found in areas under high anthropic intervention (Simonneau et al., 2016), which brings us back to the fact that these can be used as indicators of regeneration that point to differences even in advanced stages of recovery of reforested areas.

The greater association of qualitative factors with RF could indicate that these fragments already have good stability and high plant complexity, thus 
favoring the ecological relationships related to energy flows in the ecosystem (Rosa et al., 2018b) and the diversity of spiders. However, the composition of spider families is also influenced by the possibility of trophic niches present in the ecosystems, which leads to the assumption that places where the energy flow is high have the greatest diversity of detritivore soil organisms (Braschler and Baur, 2016), which serve as prey to spiders. This fact may explain why the environmental variables of litter quality and $\mathrm{C}$ flow, allied to the composition of the spider fauna are sufficient to indicate differences between $\mathrm{NF}$ and $\mathrm{RF}$, thus defining the Hahniidae, Lycosidae, Anapidae, Linyphiidae, Salticidae, Scytodidae, Corinnidae, Dipluridae, Nemesiidae and Palpimanidae families (Table 2) as sensitive indicators for different Araucaria forests.

\section{Conclusions}

The abundance of families of soil spiders is higher in native Araucaria forests only in the summer; in winter, there was no difference between the forests studied. Hahniidae, Anapidae, Linyphiidae, predominant in NF, were the ones that most contributed to the separation between native and reforested forests, showing the possibility of their application as indicators, even when the planted forests are in an advanced stage of regeneration. Lycosidae, Salticidae, Scytodidae, Corinnidae, Dipluridae, Nemesiidae and Palpimanidae, in general more numerous in $\mathrm{RF}_{\text {, }}$ also contribute significantly to the separation of the forests studied and can serve as quality indicators. The soil properties related to the energy flow $\left(\mathrm{C}\right.$-org, $\left.\mathrm{C}-\mathrm{CO}_{2}, q \mathrm{CO}_{2}\right)$, in addition to C-Lt, were determinant for the presence of different families of soil spiders in native and reforested Araucaria forests. In addition, physical soil properties such as total porosity, density and soil moisture also contribute to the differential distributions of the families of the soil spiders.

The great advantage of the identification of spiders at the family level, as opposed to species level is that it can be adopted when a rapid assessment on biodiversity is required, in areas where the spider fauna is poorly known taxonomically. On the other hand, identification at the species level is important information which sheds light on native species. Developing such knowledge will make it possible to infer management practices in the recovery of degraded forests, in agricultural environments or at the edges of forests to improve the efforts of preservation of both spiders and ecosystems.

\section{Acknowledgments}

The first author is grateful to the Federal Institute of Education, Science and Technology of the South of Minas Gerais for the financial support to translate this article. E.J.B.N. Cardoso, D. Baretta, and A.D. Brescovit acknowledge the subsidy of a Brazilian National Council for Scientific and Technological Development (CNPq) productivity grant (Processes no. 305193/2016-3, no. 305939/2018-1, and no. 303903/2019-8, respectively).

\section{Authors' Contributions}

Conceptualization: Cardoso, E.J.B.N.; Baretta, D.; Pereira, J.M. Data acquisition: Pereira, J.M.; Brescovit, A.D.; Baretta, D. Data analysis: Baretta, D.; Pereira, J.M.; Oliveira Filho, L.C.I.; Baretta, C.R.D.M. Design of methodology: Pereira, J.M.; Cardoso, E.J.B.N.; Baretta, D. Writing and editing: Pereira, J.M.; Oliveira Filho, L.C.I.; Segat, J.C.; Cardoso, E.J.B.N.; Brescovit, A.D.; Baretta, C.R.D.M.; Baretta, D.

\section{References}

Alef, K.; Nannipieri, P. 1995. Methods in Applied Soil Microbiology and Biochemistry. Academic Press, London, UK.

Almada, M.S.; Sarquis, J.A. 2017. Diversity of spiders of soil and their relationship with heterogeneous environments from the Parque General San Martín, Entre Ríos, Argentina. Revista Mexicana de Biodiversidad 88: 654-663 (in Spanish, with abstract in English).

Alvares, C.A.; Stape, J.L.; Sentelhas, P.C.; Gonçalves, J.L.M.; Sparovek, G. 2014. Köppen's climate classification map for Brazil. Meteorologische Zeitschrift 22: 711-728.

Anderson, T.H.; Domsch, K.H. 1993. The metabolic quotient for $\mathrm{CO}_{2}\left(q \mathrm{CO}_{2}\right)$ as a specific activity parameter to assess the effects of environmental conditions, such as $\mathrm{pH}$, on the microbial biomass of forest soils. Soil Biology and Biochemistry 25: 393-395.

Baretta, D.; Brescovit, A.D.; Knysak, I.; Cardoso, E.J.B.N. 2007. Trap and soil monolith sampled edaphic spiders (Arachnida: Araneae) in Araucaria angustifolia forest. Scientia Agricola 64: 375-383.

Benati, K.R.; Souza-Alves, J.P.; Silva, E.A.; Peres, M.C.L.; Coutinho, É.O. 2005. Comparative aspects of spider communities (Araneae) in two Atlantic Forest remnants of Bahia, Brazil. Biota Neotropica 5: 79-87 (in Portuguese, with abstract in English).

Birkhofer, K.; Fevrier, V.; Heinrich, A.E.; Rink, K.; Smith, H.G. 2018. The contribution of CAP greening measures to conservation biological control at two spatial scales. Agriculture, Ecosystems and Environment 255: 84-94.

Blake, G.R.; Hartge, K.H. 1986. Bulk density. p. 363-375. In: Klute, A., ed. Methods of soil analysis. Part 1. Physical and mineralogical methods. Soil Science Society of America, Madison, WI, USA.

Braschler, B.; Baur, B. 2016. Diverse effects of a seven-year experimental grassland fragmentation on major invertebrate groups. PLoS One 11: e0149567.

Brennan, K.E.C.; Majer, J.D.; Moir, M.L. 2005. Refining sampling protocols for inventorying invertebrate biodiversity: influence of drift-fence length and pitfall trap diameter on spiders. Journal of Arachnology 33: 681-702.

Brescovit, A.D.; Bonaldo, A.B.; Rheims, C.A. 2004. A new species of Drymusa Simon, 1891 (Araneae, Drymusidae) from Brazil. Zootaxa 697: 1-5. 
Casida Jr.; L.E.; Klein, D.A.; Santoro, T. 1964. Soil dehydrogenase activity. Soil Science 98: 371-376.

Cattin, M.-F.; Blandenier, G.; Banašek-Richter, C.; Bersier, L.-F. 2003. The impact of mowing as a management strategy for wet meadows on spider (Araneae) communities. Biological Conservation 113: 179-188.

Cerveira, A.M.; Jackson, R.R. 2005. Specialised predation by Palpimanus sp. (Araneae: Palpimanidae) on jumping spiders (Araneae: Salticidae). Journal of East African Natural History 94: 303-317.

DiCarlo, L.A.S.; DeBano, S.J. 2019. Spider community responses to grassland restoration: balancing trade-offs between abundance and diversity. Restoration Ecology 27: 210-219

Empresa Brasileira de Pesquisa Agropecuária [EMBRAPA]. 2011. Manual of Soil Analysis Methods = Manual de Métodos de Análise de Solo. 2ed. Embrapa Solos, Rio de Janeiro, RJ, Brazil (in Portuguese).

Foelix, R.F. 2010. Biology of Spiders. 3ed. Oxford University Press, New York, NY, USA.

Food and Agriculture Organization [FAO]. 2015. International Soil Classification System for Naming Soils and Creating Legends for Soil Maps. FAO, Rome, Italy. (World Soil Resources Reports, 106).

Gee, G.W.; Or, D. 2002. Particle-size analysis. p. 255-293. In: Dane, J.H.; Topp, G.C., eds. Methods of soil analysis. Part 4. Physical methods. Soil Science Society of America, Madison, WI, USA

Gravesen, E. 2008. Linyphiid spider populations in sustainable wheat-clover bi-cropping compared to conventional wheatgrowing practice. Journal of Applied Entomology 132: 545-556.

Indicatti, R.P.; Lucas, S.M.; Ott, R.; Brescovit, A.D. 2008. Litter dwelling mygalomorph spiders (Araneae: Microstigmatidae, Nemesiidae) from Araucaria forests in southern Brazil, with the description of five new species. Revista Brasileira de Zoologia 25: 529-546.

Jung, M.P.; Kim, S.T.; Kim, H.; Lee, J.H. 2008a. Species diversity and community structure of ground-dwelling spiders in unpolluted and moderately heavy metal-polluted habitats. Water, Air, and Soil Pollution 195: 15-22.

Jung, M.P.; Kim, S.T.; Kim, H.; Lee, J.H. 2008b. Biodiversity and community structure of ground-dwelling spiders in four different field margin types of agricultural landscapes in Korea. Applied Soil Ecology 38: 185-195.

Kajak, A.; Kupryjanowicz, J.; Petrov, P. 2000. Long term changes in spider (Araneae) communities in natural and drained fens in the Biebrza River Valley. Ekológia 19: 55-64.

Lo-Man-Hung, N.F.; Marichal, R.; Candiani, D.F.; Carvalho, L.S.; Indicatti, R.P.; Bonaldo, A.B.; Cobo, D.H.R.; Feijoo, A.M.; Tselouiko, S.; Praxedes, C.; Brown, G.; Velasquez, E.; Decaëns, T.; Oszwald, J.; Martins, M.; Lavelle, P. 2011. Impact of different land management on soil spiders (Arachnida: Araneae) in two Amazonian areas of Brazil and Colombia. Journal of Arachnology 39: 296-302.

Malumbres-Olarte, J.; Barratt, B.I.P.; Vink, C.J.; Paterson, A.M.; Cruickshank, R.H.; Ferguson, C.M.; Barton, D.M. 2013. Habitat specificity, dispersal and burning season: recovery indicators in New Zealand native grassland communities. Biological Conservation 160: 140-149.
Mantyka-Pringle, C.S.; Visconti, P.; Di Marco, M.; Martin, T.G.; Rondinini, C.; Rhodes, J.R. 2015. Climate change modifies risk of global biodiversity loss due to land-cover change. Biological Conservation 187: 103-111.

Marc, P.; Canard, A.; Ysnel, F. 1999. Spiders (Araneae) useful for pest limitation and bioindication. Agriculture, Ecosystems and Environment 74: 229-273.

Morriën, E.; Hannula, S.E.; Snoek, L.B.; Helmsing, N.R.; Zweers, H.; Hollander, M.; Soto, R.L.; Bouffaud, M.-L.; Buée, M.; Dimmers, W.; Duyts, H.; Geisen, S.; Girlanda, M.; Griffiths, R.I.; Jørgensen, H.-B.; Jensen, J.; Plassart, P.; Redecker, D.; Schmelz, R.M.; Schmidt, O.; Thomson, B.C.; Tisserant, E.; Uroz, S.; Winding, A.; Bailey, M.J.; Bonkowski, M.; Faber, J.H.; Martin, F.; Lemanceau, P.; de Boer, W.; van Veen, J.A.; van der Putten, W.H. 2017. Soil networks become more connected and take up more carbon as nature restoration progresses. Nature Communications 8: 14349.

Oxbrough, A.G.; Gittings, T.; O'Halloran, J.; Giller, P.S.; Kelly, T.C. 2007. Biodiversity of the ground-dwelling spider fauna of afforestation habitats. Agriculture, Ecosystems and Environment 120: 433-441.

Pereira, J.M.; Segat, J.C.; Baretta, D.; Vasconcellos, R.L.F.; Baretta, C.R.D.M.; Cardoso, E.J.B.N. 2017. Soil macrofauna as a soil quality indicator in native and replanted Araucaria angustifolia forests. Revista Brasileira de Ciência do Solo 41: e0160261.

Pereira, J.M.; Baretta, D.; Bini, D.; Vasconcellos, R.L.F.; Cardoso, E.J.B.N. 2013. Relationships between microbial activity and soil physical and chemical properties in native and reforested Araucaria angustifolia forests in the state of São Paulo, Brazil. Revista Brasileira de Ciência do Solo 37: 572-586.

Picchi, M.S.; Bocci, G.; Petacchi, R.; Entling, M.H. 2016. Effects of local and landscape factors on spiders and olive fruit flies. Agriculture, Ecosystems and Environment 222: 138-147.

Pommeresche, R.; Bakken, A.K.; Korsaeth, A. 2013. Abundance and diversity of spiders (Araneae) in barley and young leys. Journal of Arachnology 41: 168-175.

Rix, M.G.; Huey, J.A.; Main, B.Y.; Waldock, J.M.; Harrison, S.E.; Comer, S.; Austin, A.D.; Harvey, M.S. 2017. Where have all the spiders gone? The decline of a poorly known invertebrate fauna in the agricultural and arid zones of southern Australia. Austral Entomology 56: 14-22.

Rodriguez-Artigas, S.M.; Ballester, R.; Corronca, J.A. 2016. Factors that influence the beta-diversity of spider communities in northwestern Argentinean Grasslands. PeerJ 4: e1946.

Rosa, M.G.; Santos, J.C.P.; Brescovit, A.D.; Mafra, Á.L.; Baretta, D. 2018a. Spiders (Arachnida: Araneae) in agricultural land use systems in subtropical environments. Revista Brasileira de Ciência do Solo 42: e0160576.

Rosa, M.G.; Santos, J.C.P.; Brescovit, A.D.; Mafra, Á.L.; Baretta, D. 2018b. The intensification of soil use can affect the spider biodiversity? Scientia Agraria 19: 256-265 (in Portuguese, with abstract in English).

Sabais, A.C.W.; Scheu, S.; Eisenhauer, N. 2011. Plant species richness drives the density and diversity of Collembola in temperate grassland. Acta Oecologica 37: 195-202.

Schmidt, M.H.; Thies, C.; Nentwig, W.; Tscharntke, T. 2008. Contrasting responses of arable spiders to the landscape matrix at different spatial scales. Journal of Biogeography 35: 157-166. 
Silva, G.O.; Ott, R. 2017. Short-term spider community monitoring after cattle removal in grazed grassland. Iheringia. Série Zoológica 107: e2017033.

Simonneau, M.; Courtial, C.; Pétillon, J. 2016. Phenological and meteorological determinants of spider ballooning in an agricultural landscape. Comptes Rendus Biologies 339: 408416.

Van Raij, B.; Andrade, J.C.; Cantarella, H.; Quaggio, J.A. 2001. Chemical Analysis for Fertility Evaluation of Tropical Soils = Análise Química para Avaliação da Fertilidade de Solos Tropicais. Instituto Agronômico, Campinas, SP, Brazil (in Portuguese).

Vance, E.D.; Brookes, P.C.; Jenkinson, D.S. 1987. An extraction method for measuring soil microbial biomass C. Soil Biology and Biochemistry 19: 703-707.

World Spider Catalog (2019). World Spider Catalog. Version 21.0. Natural History Museum Bern, online at http://wsc.nmbe.ch [Accessed Mar 18, 2019]. doi: 10.24436/2
Wrege, M.S.; Sousa, V.A.; Fritzsons, E.; Soares, M.T.S.; Aguiar, A.V. 2016. Predicting current and future geographical distribution of Araucaria in Brazil for fundamental niche modeling. Environment and Ecology Research 4: 269-279.

Wrege, M.S.; Fritzsons, E.; Soares, M.T.S.; Sousa, V.A. 2015. Climatic factors related to ecosystem services: the case of Araucaria = Variáveis climáticas relacionadas aos serviços ambientais: estudo de caso da araucária. p. 242-247. In: Parron, L.M.; Garcia, J.R.; Oliveira, E.B.; Brown, G.G.; Prado, R.B., eds. Environmental services in agricultural and forest systems of the Atlantic Forest Biome = Serviços ambientais em sistemas agrícolas e florestais do Bioma Mata Atlântica. Embrapa, Brasília, DF, Brazil (in Portuguese).

Yang, Z.; Nolte, S.; Wu, J. 2017. Tidal flooding diminishes the effects of livestock grazing on soil micro-food webs in a coastal saltmarsh. Agriculture, Ecosystems and Environment 236: 177186. 